\title{
Relationship of Smoking with Fatigue and Depression in Patients with Multiple Sclerosis
}

\author{
Multipl Skleroz Hastalarında Sigaranın Yorgunluk ve Depresyon ile İlişkisi
}

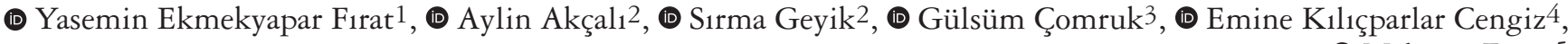
(1) Mehmet Erten'

\author{
1SANKO University Faculty of Medicine, Department of Neurology, Gaziantep, Turkey \\ ${ }^{2}$ Gaziantep University Faculty of Medicine, Department of Neurology, Gaziantep, Turkey \\ 3Hatay State Hospital, Clinic of Neurology, Hatay, Turkey \\ ${ }^{4}$ Dr. Ersin Arslan Training and Research Hospital, Clinic of Neurology, Gaziantep, Turkey \\ 5 Medical Biochemistry Laboratory, Public Health Laboratory, Malatya, Turkey
}

\begin{abstract}
Objective: The relationship between smoking and the risk and progression of multiple sclerosis (MS) is known. We investigated the role of smoking on fatigue, depression, and disability in patients with MS.

Materials and Methods: Three groups were included in our study. These were smokers with MS ( $\mathrm{n}=40$ ), non-smokers with MS ( $\mathrm{n}=40$ ), and healthy smokers $(\mathrm{n}=50)$ groups. Patients were diagnosed as having MS according to the 2010 revised McDonald diagnostic criteria. This study used a sociodemographic follow-up form, the neurological fatigue index, Fagerstrom test for nicotine dependence, and Beck depression inventory.

Results: We showed that MS patients felt more fatigue than healthy individuals, but there was no difference regarding fatigue levels between smokers with MS and non-smokers with MS. In addition, we determined that smoking increased the level of depression, or those with depression might be smoking more.

Conclusion: We believe that smoking is not associated with MS fatigue. However, smoking may be associated with the severity of patients' depression. Keywords: Multiple sclerosis, cigarette, fatigue, depression
\end{abstract}

Öz

Amaç: Sigara içmekle, multipl skleroz (MS) riski ve hastalığın progresyonu arasında varolan ilişki bilinmektedir. Bu araştırmada, sigara içiminin MS hastalarında yorgunluk, depresyon ve özürlülük üzerine etkisinin araştırılması amaçlanmıştır.

Gereç ve Yöntem: Çalışmamıza, 2010 revize McDonald tanı kriterlerine göre MS tanısı almış sigara içen ve içmeyen 40 'ar hasta ve 50 sigara içen sağlıklı bireyden oluşan 3 grup dahil edildi. Bu çalışmada sosyodemografik takip formu, nörolojik yorgunluk indeksi, Fagerstrom nikotin bağımlılık testi ve Beck depresyon ölçeği kullanıldı.

Bulgular: MS'li hastalarda yorgunluğun sağlıklı kişilere göre daha fazla olduğu, ancak sigara içen ve içmeyen MS hastalarının yorgunluk düzeyleri arasında anlamlı bir farklılık olmadığı saptandı. Bunun yanı sıra sigara içiminin depresyonun düzeyini artırdı $\breve{g} 1$ ya da depresyonu olanların daha fazla sigara kullanıyor olabileceği belirlendi.

Sonuç: Sigara ile MS yorgunluğunun ilişkili olmadığını ancak sigara kullanımının hastaların depresyon düzeyi ile ilişkili olabileceğini düşünmekteyiz.

Anahtar Kelimeler: Multipl skleroz, sigara, yorgunluk, depresyon

Address for Correspondence/Yazışma Adresi: Yasemin Ekmekyapar Fırat MD, SANKO University Faculty of Medicine, Department of Neurology, Gaziantep, Turkey Phone: +90 5379545659 E-mail: yaseminekmekyapar@gmail.com ORCID: orcid.org/0000-0002-2104-6003

Received/Geliş Tarihi: 28.12.2020 Accepted/Kabul Tarihi: 16.05.2021

${ }^{\circ}$ Copyright 2021 by Turkish Neurological Society

Turkish Journal of Neurology published by Galenos Publishing House. 


\section{Introduction}

Smoking is a leading preventable cause of morbidity and mortality in adults (1). Some substances in cigarettes are directly toxic to the central nervous system (CNS). Smoking contains large amounts of free radicals, which cause axonal damage. Smoking may cause brain atrophy by producing nitric oxide, a neurotoxic substance that initiates neurodegenerative processes in the cerebrospinal fluid (2).

When reactive metabolites occur during normal body metabolism, they are primarily eliminated by antioxidant defense components. However, cigarette smoke causes free radical production and oxidative stress over antioxidant capacity. As a result, muscle fatigue increases with oxidative stress, and physical performance decreases with muscle fiber damage (3). In a study that used electrical stimulation to evaluate the maximum voluntary muscle function and fatigue performed by the quadriceps femoris muscle of smokers and non-smokers, muscle fatigue was higher in smokers (4). Also, smoking caused fatigue by preventing the maximum oxygen uptake $(5,6)$.

The relationship between smoking and the risk of multiple sclerosis (MS) and disease progression is known $(7,8)$. In a study conducted in Norway, 22,312 healthy volunteers were followed regarding diseases for which smoking was a risk factor. MS developed in 87 volunteers, 65 of whom (75.6\%) were smokers. There was a significant relationship between smoking and the development of MS (9). In a meta-analysis evaluating 47 studies, smokers had more than a $50 \%$ risk of developing MS (10). In addition, mortality was higher in patients with MS who smoked $(1,7,8,11)$

MS is an autoimmune, inflammatory, and chronic disease affecting the CNS white and gray matter, which usually presents in the young adult (20-40) age group and mainly progresses with relapses and remissions. The most common form is characterized by periods of relapse and remission. MS is considered the most important demyelinating disease of the CNS (12).

Fatigue is a common symptom in patients with MS and significantly affects the quality of life of patients. Patients perceive fatigue as a very different, abnormal, and excessive feeling of tiredness (13). The neurological fatigue index (NFI-MS) is a onedimensional test specifically created to evaluate fatigue in MS. It questions the effects of fatigue on activities of daily living (14). The NFI-MS was developed in 2010 by Mills et al. (15) It is a questionnaire consisting of 23 items and four subscales. These subscales assess physical (eight items), cognitive (four items), recovery with diurnal sleep or rest (six items), and abnormal nocturnal sleep and sleepiness (five items). Each of the four subscales is scored as a total, with a higher score indicating more fatigue. However, the total score is not calculated by adding all of them. In addition, an NFI-MS summary score containing 10 items (seven physical and three cognitive items) can be calculated (15).

Depression is a common clinical condition in MS and a common cause of fatigue. Smoking and nicotine addiction have been associated with depression, especially with recurrent major depression. This risk may increase with the number of cigarettes consumed and the degree of nicotine addiction (13). It is thought that genetic factors that predispose an individual to nicotine addiction and depression are shared (16).

Fatigue causes depression by negatively affecting daily life activities in patients with MS, and smoking increases depression and fatigue. This study investigates the relationship between smoking, fatigue, and depression in patients with MS.

\section{Materials and Methods}

This study was conducted prospectively. A total of 80 patients, 40 smokers and 40 non-smokers, diagnosed as having MS according to the 2010 revised Mc Donald diagnostic criteria and admitted to the outpatient clinic of the Neurology Department of Gaziantep University Hospital were included in the study group. Also, 50 smokers were included in the healthy control group. An informed consent form was obtained from all participants. The NFI-MS was used to determine the fatigue of patients. The sociodemographic characteristics, age, gender, marital status, educational status, employment status, duration of illness, number of attacks, and questionnaire results of all patients included in the study were recorded on the patient follow-up forms. The disability status of patients was determined using the expanded disability status scale. Patients were grouped according to whether they received disease-modifying therapy (DMT). The patients who smoked were identified, and the Fagerstrom test for nicotine dependence (FTND) was used to determine their addiction levels. Karl O. Fagerstrom developed the FTND to assess the level of physical dependence on cigarettes. The test consists of six closed-ended questions. The validity and reliability of the test in Turkish were performed by Uysal et al. (17), and the alpha reliability coefficient was 0.56 (moderate reliability). The depression status of healthy smokers, smokers with MS, and non-smokers with MS were determined by applying the Beck depression inventory (BDI).

This study was approved by the Ethics Committee of Gaziantep University Faculty of Medicine on November 1, 2016, and the decision number 2016/11, date: 11.01.2016.

\section{Statistical analysis}

All data analyses in this study were performed with the SPSS 20 statistical package program. For continuous variables with normal distribution, numbers, mean, and standard deviation were used. Independent samples were analyzed with the t-test. ShapiroWilk was used to test the normality of the distributions. The Kruskal-Wallis test, a non-parametric test, was used for groups with variables that did not show normal distribution. An ANOVA test analysis was performed to investigate whether the differences were statistically significant. The Scheffe test, a post-hoc test, was used to determine which group caused the difference. A $\mathrm{p}<0.05$ was considered statistically significant.

\section{Results}

A total of 130 participants, $40(30.8 \%)$ smokers with MS, 40 (30.8\%) non-smokers with MS, and $50(38.5 \%)$ smokers in the control group, were included in the study. All three groups had similar characteristics regarding age and gender $(p>0.05)$. The mean age of patients with MS who smoked was $35.8 \pm 9.9$ years, $20(50 \%)$ were female, and $20(50 \%)$ were male. The mean age of patients with MS who did not smoke was $37.3 \pm 8.7$ years, 29 $(72.5 \%)$ were female, and $11(27.5 \%)$ were male. The mean age of the control group was $33.4 \pm 7.2$ years, with 18 women $(36 \%)$ and 32 men (64\%). Descriptive statistics of our study are shown in Table 1. 
There was no statistically significant difference between the disease duration of smokers with MS and non-smokers with MS $(p=0.291)$ and between the number of attacks $(p=0.668)$. It was determined that there was no relationship between the duration of the disease, the number of attacks, and the DMT status of patients with MS who did not smoke $(p=0.178 ; p=0.202)$. It was found that there was no relationship between the duration of the disease and the DMT status of patients with MS who smoked ( $\mathrm{p}=0.298)$. However, there was a relationship between the number of attacks and the DMT status of patients with MS who smoked ( $\mathrm{p}=0.044)$. This difference was because the number of patients with MS who smoked who received DMT was higher than those who did not receive DMT. Therefore, according to these findings, the number of attacks in patients with MS did not differ according to smoking, but the number of attacks in this group of patients who received DMT was lower. The lowest and highest EDSS values of smokers and non-smokers with MS were similar. The mean EDSS value was 1.5, the mean EDSS for smokers was 1.38, and for non-smokers, it was 1.7. There was no statistical difference between the groups $(\mathrm{p}=0.318)$ (Table 2).

Our study found a statistically significant difference between the NFI-MS index subgroups (physical, cognitive, recovery, sleepiness) scores and the NFI-MS summary scores of the groups. The NFI-MS subgroup and summary scores of healthy smokers were better than those of smokers and non-smokers with MS $(\mathrm{p}=0.000)$. There was no significant difference between the NFIMS subgroup and summary scores of smokers and non-smokers with MS ( $\mathrm{p}=0.996)$ (Table 3).
There was no statistically significant difference between the nicotine addiction levels of healthy smokers and the nicotine addiction levels of smokers with MS ( $p=0.451)$. Healthy smokers did not have depression, patients with MS who did not smoke had "mild" depressive symptoms, and patients with MS who smoked had "moderate" depressive symptoms (Table 4). A statistically significant difference was found between the BDI scores of all three groups $(\mathrm{p}=0.000)$.

There was an inverse relationship between education status and BDI scores in all groups. Thus, the BDI scores of those with higher education levels in all three groups were significantly lower $(\mathrm{p}=0.008)$. There was no relationship between age, gender, marital status and duration of illness, and BDI, NFI-MS, nicotine addiction, and EDSS scores ( $p>0.05$ ).

\section{Discussion}

In our study, regardless of smoking, patients with MS felt more fatigue than healthy smokers, clearly supporting the relationship between fatigue and MS. On the other hand, cigarette smoking did not affect fatigue in patients with MS. Also, patients with MS who had lower fatigue scale scores than healthy people suggested that both neuronal and physical mechanisms were affected in the symptom of fatigue.

The compounds in cigarettes affect the blood-brain barrier, cause chemokine flow, and trigger inflammation (10). Cigarettes contain 4500 possible toxic substances, such as nicotine, nitric oxide, and hydrogen cyanide, which cause inflammation, oxidative

\section{Table 1. Descriptive and demographic characteristics}

\begin{tabular}{|c|c|c|c|}
\hline & Smokers with MS $(n=40)$ & Non-smokers with MS $(n=40)$ & Control $^{*}(n=50)$ \\
\hline $\begin{array}{l}\text { Age }(\text { year }), \text { mean } \pm S D \\
(\text { min-max })\end{array}$ & $\begin{array}{l}35.8 \pm 9.9 \\
(18-58)\end{array}$ & $\begin{array}{l}37.3 \pm 8.7 \\
(19-56)\end{array}$ & $33.4 \pm 7.2$ \\
\hline Disease duration (year), mean \pm SD & $8.2 \pm 5.5$ & $7.0 \pm 4.4$ & $(20-54)$ \\
\hline Gender n (\%) & & & - \\
\hline Women & $20(50 \%)$ & $29(72.5 \%)$ & \\
\hline Men & $20(50 \%)$ & $11(27.5 \%)$ & $18(36 \%)$ \\
\hline Marital status n (\%) & & & $32(64 \%)$ \\
\hline Single & $10(25 \%)$ & $8(20 \%)$ & \\
\hline Married & $30(75 \%)$ & $32(80 \%)$ & $15(30 \%)$ \\
\hline Education status n (\%) & & & $35(70 \%)$ \\
\hline Illiterate & $1(2.5 \%)$ & $0(0 \%)$ & $0(0 \%)$ \\
\hline Primary school & $10(25 \%)$ & $17(42.5 \%)$ & $10(20 \%)$ \\
\hline Middle school & $5(12.5 \%)$ & $5(12.5 \%)$ & $9(18 \%)$ \\
\hline High school & $18(45 \%)$ & $7(17.5 \%)$ & $22(44 \%)$ \\
\hline University & $6(15 \%)$ & $11(27.5 \%)$ & $9(18 \%)$ \\
\hline
\end{tabular}

Table 2. EDSS scores of patients

\begin{tabular}{llll|} 
Group & Minimum & Maximum & p \\
Smokers with MS & 0.00 & 4.5 & 0.318 \\
Non-smokers with MS & 0.00 & 4.0 & \\
EDSS: Expanded disability status, MS: Multiple sclerosis & & \\
\hline
\end{tabular}


damage, microglial activation, white matter demyelination, and axonal degeneration $(10,18)$. Smoking induces proinflammatory cascades by producing an irritant effect on the lungs, and long-term exposure triggers autoimmunity. The MS development hypothesis suggests a cross-reaction between lung antigens and myelin antigens (18). Free radicals, such as cyanate and carbon monoxide, in cigarettes have a direct neurotoxic effect. The interaction of these factors with genetic and environmental factors increases the risk of MS in smokers, raises disease activity, accelerates brain atrophy, and increases disability $(18,19)$.

A study investigating the relationship between electroniccigarette (e-cigarette) addiction and fatigue found that fatigue level was associated with e-cigarette smoking (20). Another study reported fatigue in $86.6 \%$ of patients with MS, and smoking was associated with MS fatigue (13). In their study, Aktan et al. (21) found that the daily walking distance was lower in patients with MS who smoked. It was also shown that smoking was associated with shortness of breath and degree of fatigue during exertion. Since smoking impairs protein synthesis in skeletal muscles and reduces lung capacity, lead to early fatigue $(3,22)$.

In our study, according to the BDI scores, non-smokers with MS were mildly depressed, whereas smokers with MS were moderately depressed. In our study, the depression levels of smokers and nonsmokers were different, and depression was not found in healthy smokers. It was suggested that the already existing depression in patients with MS increased with smoking or that patients with a higher BDI score smoked more $(23,24)$. The prevalence of depression in patients with MS is two to three times higher than that of the general population, and its lifetime prevalence is reported to be around 50\% (25,26). Also, depressive patients with MS who smoke were more unsuccessful in quitting smoking (27).

Smoking, fatigue, and depression affect cognitive functions. Depression and fatigue in patients with MS occur due to the combination of psychosocial, neurobiological, and diseaserelated factors (28). Cortical atrophy is associated with fatigue and depression in patients with MS (29). Brain atrophy is caused by proinflammatory stimuli and neurotoxic agents in smokers without MS and in patients with MS (30,31).

The BENEFIT-11 study reported that smoking negatively affected the cognitive functions of patients with MS in the long term and neurofilament light chain (NfL) levels were $20 \%$ higher in smokers with MS. Smoking initiates neuroinflammatory and neurodegenerative processes and increases NfL levels by causing brain atrophy and affects cognitive functions. Quitting smoking in the early period after an MS diagnosis may preserve long-term cognitive functions and neuroaxonal integrity independent of treatments (32).

Table 3. Comparison of BDI score, NFI-MS score, disease duration, EDSS score of patients with MS and their smoking status

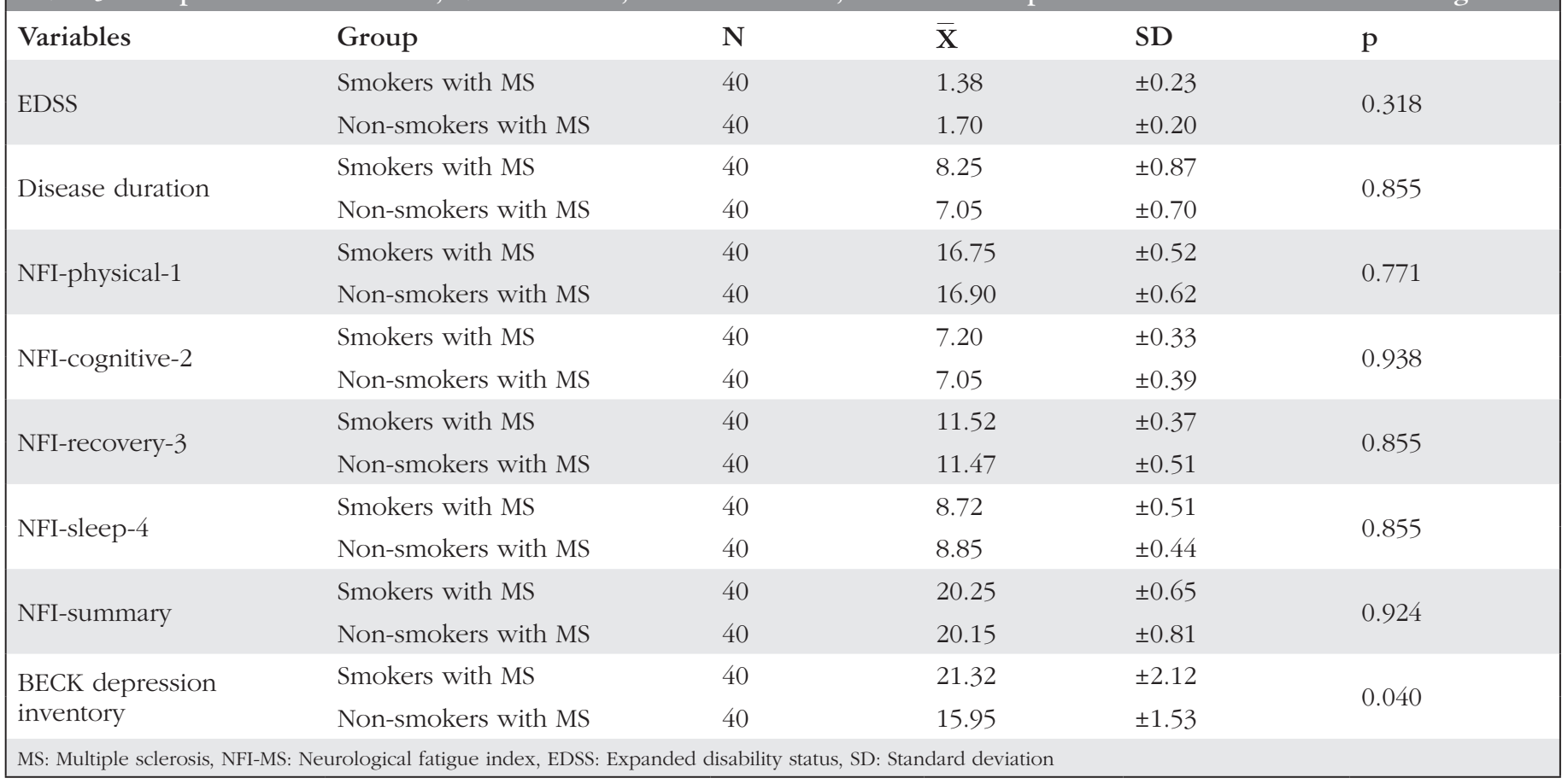

Table 4. Beck depression inventory scores of the groups

\section{Groups}

Smokers with MS

Non-smokers with MS

Healthy smokers

MS: Multiple sclerosis, SD: Standard deviation
Score mean $\pm \mathrm{SD}$

$21.325 \pm 13.42$

$15.950 \pm 9.72$

$5.460 \pm 5.08$ p value

$\mathrm{p}<0.05$ 
This study found no significant relationship between smoking and gender and disability and EDSS values. MS is a disease that is usually seen at a young age, causes disability in patients, and severely affects their quality of life. In some studies, smoking increased disability and EDSS score, whereas other studies concluded no such effect $(29,33,34,35)$. There are studies in which male patients who smoke have higher EDSS (34).

Our study determined no relationship between age, gender, marital status, duration of illness, BDI, NFI-MS, nicotine addiction, and EDSS scores. There was no significant relationship between education level and NFI-MS fatigue, EDSS, and nicotine addiction status scores, whereas those with higher education levels, had significantly lower BDI scores. In some studies, no relationship was found between educational status, fatigue, and depression. However, others found that the severity of fatigue and depression decreased $(28,36,37)$.

\section{Study Limitations}

There seems to be a limited number of studies on the relationship between cigarette smoking and MS symptoms. The conspicuous limitations of our study were that it did not include long-term observations, and the number of patients was low.

\section{Conclusion}

Consistent with the literature, moderate and mild depression was present in patients with MS, and smoking increased depression in patients with MS. However, no significant relationship was found between smoking and NFI-MS fatigue score, EDSS score, use of DMT, and the number of attacks in patients with MS. Further studies should be conducted by reaching more patients with MS, adding additional biochemical parameters, and investigating the relationship between smoking, fatigue, and depression. In addition, there is a need for studies examining the relationship between smoking and other factors in MS and its pathophysiological causes.

\section{Ethics}

Ethics Committee Approval: This study was approved by the Ethics Committee of Gaziantep University Faculty of Medicine on November 1, 2016, and the decision number 2016/11, date: 11.01.2016.

Informed Consent: An informed consent form was obtained from all participants.

Peer-review: Externally peer-reviewed.

\section{Authorship Contributions}

Concept: Y.E.F., A.A., Design: Y.E.F., A.A., Data Collection or Processing: Y.E.F., A.A., S.G., G.Ç., E.K.C., M.E., Analysis or Interpretation: Y.E.F., A.A., S.G., G.Ç., E.K.C., M.E., Literature Search: Y.E.F., A.A., Writing: Y.E.F., A.A.

Conflict of Interest: No conflict of interest was declared by the authors.

Financial Disclosure: The authors declared that this study received no financial support.

\section{References}

1. Vandebergh M, Goris A. Smoking and multiple sclerosis risk: a Mendelian randomization study. J Neurol 2020;267:3083-3091.

2. Durazzo TC, Meyerhoff DJ, Nixon SJ. Chronic cigarette smoking: implications for neurocognition and brain neurobiology. Int J Environ Res Public Heal 2010;7:3760-3791.
3. Degens H, Gayan-Ramirez G, Van Hees HWH. Smoking-induced skeletal muscle dysfunction: from evidence to mechanisms. Am J Respir Crit Care Med 2015;191:620-625.

4. Wüst RCI, Christopher IM, De Haan A, et al. Skeletal muscle properties and fatigue resistance in relation to smoking history. Eur J Appl Physiol 2008;104:103-110.

5. Devasahayam AJ, Kelly LP, Wallack EM, Ploughman M. Oxygen cost during mobility tasks and its relationship to fatigue in progressive multiple sclerosis. Arch Phys Med Rehabil 2019;100:2079-2088.

6. Lee CL, Chang WD. The effects of cigarette smoking on aerobic and anaerobic capacity and heart rate variability among female university students. Int J Womens Health 2013;5:667-679.

7. Di Pauli F, Reindl M, Ehling R, et al. Smoking is a risk factor for early conversion to clinically definite multiple sclerosis. Mult Scler 2008;14:10261030.

8. Hedström AK, Hillert J, Olsson T, Alfredsson L. Smoking and multiple sclerosis susceptibility. Eur J Epidemiol 2013;28:867-874.

9. Riise T, Nortvedt MW, Ascherio A. Smoking is a risk factor for multiple sclerosis. Neurology 2003;61:1122-1124.

10. Zhang P, Wang R, Li Z, et al. The risk of smoking on multiple sclerosis: a meta-analysis based on 20,626 cases from case-control and cohort studies. PeerJ 2016;4:1-19.

11. Ciccolo JT, Lo AC, Jennings EG, Motl RW. Rationale and design of a clinical trial investigating resistance training as an aid to smoking cessation in persons with multiple sclerosis. Contemp Clin Trials 2012;33:848-852.

12. Dobson R, Giovannoni G. Multiple sclerosis-a review. Eur J Neurol 2019;26:27-40.

13. Weiland TJ, Jelinek GA, Marck CH, et al. Clinically significant fatigue: prevalence and associated factors in an international sample of adults with multiple sclerosis recruited via the internet. PLoS One 2015;10:e115541.

14. Derksen A, Mokkink LB, Rietberg MB, et al. Validation of a Dutch version of the Neurological Fatigue Index (NFI-MS) for patients with multiple sclerosis in the Netherlands. Qual Life Res 2013;22:2435-2441.

15. Mills RJ, Young CA, Pallant JF, Tennant A. Development of a patient reported outcome scale for fatigue in multiple sclerosis: the Neurological Fatigue Index (NFI-MS). Health Qual Life Outcomes 2010;8:22.

16. Marrie RA. Environmental risk factors in multiple sclerosis aetiology. Lancet Neurol 2004;3:709-718.

17. Uysal MA, Kadakal F, Karşidag C, et al. Fagerstrom test for nicotine dependence: reliability in a Turkish sample and factor analysis. Tuberk Toraks 2004;52:115-121.

18. Arneth B. Multiple sclerosis and smoking. Am J Med 2020;133:783-788.

19. Rosso M, Chitnis T. Association between cigarette smoking and multiple sclerosis: a review. JAMA Neurol 2020;77:245-253.

20. Zvolensky MJ, Manning K, Garey L, Mayorga NA, Peraza N. Fatigue severity and electronic cigarette beliefs and use behavior. Addict Behav 2019;97:1-6.

21. Aktan R, Ozalevli S, Ozakbas S. Effects of cigarette smoking on respiratory problems and functional levels in multiple sclerosis patients. Mult Scler Relat Disord 2018;25:271-275.

22. Ergin C, Yurdalan SU, Demirbuken I, Zengin O. Fatigue and physical activity levels of smoking and non-smoking healthy sedentary individuals. Clin Exp Heal Sci 2016;6:51-55.

23. Gascoyne CR, Simpson S, Chen J, Mei I, Marck CH. Modifiable factors associated with depression and anxiety in multiple sclerosis. Acta Neurol Scand 2019;140:204-211.

24. Kahraman T, Ozdogar AT, Abasiyanik Z, Ozakbas S; Multiple Sclerosis Research Group. Associations between smoking and walking, fatigue, depression, and health-related quality of life in persons with multiple sclerosis. Acta Neurol Belg 2020 Mar 28. Epub ahead of print.

25. Ormstad H, Simonsen CS, Broch L, et al. Chronic fatigue and depression due to multiple sclerosis: Immune-inflammatory pathways, tryptophan catabolites and the gut-brain axis as possible shared pathways. Mult Scler Relat Disord 2020;46:102533.

26. Fiorillo A, Garcia-Toro M, Jelinek GA, et al. Longitudinal associations of modifiable lifestyle factors with positive depression-screen over 2.5-years in an International Cohort of people living with multiple sclerosis. Front Psychiatry 2018;9:1-16. 
27. Newland P, Flick L, Salter A, Dixon D, Jensen MP. The link between smoking status and co-morbid conditions in individuals with multiple sclerosis (MS). Disabil Health J 2017;10:587-591.

28. Soyuer F, Ünalan D, Mirza M. Depressive symptoms in multiple sclerosis and the association with sociodemographic factors and functional status. Turk J Neurol 2010;16:31-35.

29. Zivadinov R, Weinstock-Guttman B, Hashmi K, et al. Smoking is associated with increased lesion volumes and brain atrophy in multiple sclerosis. Neurology 2009;73:504-510

30. Lazzarotto A, Margoni M, Franciotta S, et al. Selective cerebellar atrophy associates with depression and fatigue in the early phases of relapse-onset multiple sclerosis. Cerebellum 2020;19:192-200.

31. Yang Z, Zhang Y, Cheng J, Zheng R. Meta-analysis of brain gray matter changes in chronic smokers. Eur J Radio 2020;132:1-6.
32. Cortese M, Munger KL, Martínez-Lapiscina EH, et al. Vitamin D, smoking, $\mathrm{EBV}$, and long-term cognitive performance in MS: 11-year follow-up of BENEFIT. Neurology 2020;94:1950-1960.

33. Healy BC, Ali EN, Guttmann CRG, et al. Smoking and disease progression in multiple sclerosis. Arch Neurol 2009;66:858-864.

34. Gedizlioğlu M, Çe P, Ekmen D. Cigarette Smoking in Multiple Sclerosis and Its Impact on the Disability. Turk Norol Derg 2010;16:27-30.

35. Javizian O, Metz LM, Deighton S, Koch MW. Smoking does not influence disability accumulation in primary progressive multiple sclerosis. Eur J Neurol 2017;24:624-630.

36. Lerdal A, Gulowsen Celius E, Krupp L, Dahl AA. A prospective study of patterns of fatigue in multiple sclerosis. Eur J Neurol 2007;14:1338-1343.

37. Tedeschi G, Dinacci D, Lavorgna L, et al. Correlation between fatigue and brain atrophy and lesion load in multiple sclerosis patients independent of disability. J Neurol Sci 2007;263:15-19. 